\title{
Analysis of Human Powered Sanitization Sprayer
}

\author{
Nitin Sawarkar ${ }^{1}$, Tushar Raut ${ }^{2}$, Chetan Lanjewar $^{3}$, Vivek Ingole $^{4}$, Nikhil Dhamgaye $^{5}$ \\ ${ }^{1}$ Asst Professor, Wainganga College of Engineering and Management, Maharashtra, India \\ ${ }^{2,3,4,5}$ U.G. Student, Wainganga College of Engineering and Management, Maharashtra, India
}

Received on: 20 May, 2021

Revised on: 26 June, 2021

Published on: 28 June, 2021

\begin{abstract}
This paper addresses the design and analysis of a Human Powered Sanitization Sprayer (HPSP). The main motive of this paper is to sanitize the surroundings around us. As we all know the current situation of the novel corona virus, the maintenance of the hygiene is must to prevent the spread of this deadly virus also known as Covid-19. So, to sanitize the surfaces around us we have designed the human powered sprayer machine which will be cost efficient as well as it does not require any external source of power.
\end{abstract}

Keywords- Sprayer, Sanitization, Nozzle, Analysis, Human Powered.

\section{I- INTRODUCTION}

\section{$\mathbf{C}$}

OVID-19 is a disease caused by a new strain of corona virus. 'CO' stands for corona, 'VI' for virus, and 'D' for disease. Formerly, this disease was referred to as '2019 novel corona virus' or '2019-nCoV'. Contactless technology is the need in this COVID-19 pandemic. Corona virus spreads when an infected person comes in contact with other people and this chain continues. Although sanitizers help by preventing the spread of this virus. In current scenario preventive measures and healthy life style with efficient immune system have been suggested by WHO to fight and stay safe from COVID-19. Adaptation of effective hygiene is vital, where one of the best advices by WHO is to wash or sanitize your hands and surroundings frequently with soap or $>60 \%$ alcoholic sanitizer, respectively. The purpose of this paper is to design and analyse the Human Powered Sanitization Sprayer. Its mobility is main strength of this project. The main purpose for the development of this project is to utilize the human powered bicycle for communicating where electricity is unavailable or impractical. Energy has generally been applied through the use of the arms, hands, etc. This portable spraying system is an assembly of a modified sprocket-pump assembly, tank and adjustable sprayer can be mounted on bicycle available.

Here we have use six nozzles which can cover the maximum area in front at the $180^{\circ}$ degrees where each nozzle will cover around $30^{\circ}$ degrees.

The main advantage of this project is that it does not require any external power as it is completely manual and can be fabricated at very low cost and the parts are also easily available in the market .

\section{II -LITERATURE REVIEW}

This chapter discusses about the previous researches that have been done which related to this project. This project requires good understanding of the knowledge about drying method. Therefore, executing a research is necessary to obtain all the information available and related to this topic. The information or literature reviews obtained are essentially valuable to assist in the fabrication and specification of this final year project. With this ground established, the project can be accomplished with guidance and assertiveness in achieving the target mark. The sources of the review are 


\section{International Journal of Innovations in Engineering and Science, www.ijies.net}

extracted from journal, article, books and websites. As we know that there are many existing spraying methods available but each of them has some drawbacks. Following are some ways of spraying available: -

Backpack Sprayer: One type of backpack sprayer is a compressed air sprayer with a harness that allows it to be carried on the operator's back. Another type of backpack sprayer has a hand-operated hydraulic pump that forces liquid pesticide through a hose and one or more nozzles. The pump is usually activated by moving a lever. A mechanical agitator plate may be attached to the pump plunger. Some of these sprayers can generate pressures of 100 pounds per square inch (psi) or more. Capacity of both these types of backpack sprayers is usually 5 gallons or less.

Hydraulic sprayers consist of a tank, a pump, a lance (for single nozzles) or boom, and a nozzle (or multiple nozzles). Sprayers convert a pesticide formulation, often containing a mixture of water (or another liquid chemical carrier, such as fertilizer) and chemical, into droplets, which can be large rain-type drops or tiny almost-invisible particles. This conversion is accomplished by forcing the spray mixture through a spray nozzle under pressure. The size of droplets can be altered through the use of different nozzle sizes, or by altering the pressure under which it is forced, or a combination of both. Large droplets have the advantage of being less susceptible to spray drift, but require more water per unit of land covered. Due to static electricity, small droplets are able to maximize contact with a target organism, but very still wind conditions are required.

Lite-Trac: - It is a trading name of Holme Farm Supplies Ltd, a manufacturer of agricultural machinery registered in England and based in Peterborough. The Lite-Trac name comes from "lite tractor", due to the patented chassis design enabling the inherently very heavy machines manufactured by the company to have a light footprint for minimum soil compaction.

Engine Driver Sprayers: - This is another type sprayer is fuel operated and requires expensive fuel i.e., Diesel or petrol. Thus, the load on back of the farmer increases causes health issues. Also, the pump produces more vibrations which is hazardous to users back muscles, these pump makes unwanted noise.

\section{Problem Statement:}

To protect from this deadly virus, we have to sanitized the surface area. But existing sanitizing system covers only limited area.

This problem is solved by using and with the help of a special device known as a "Sprayer," sprayer provides optimum performance with minimum efforts.
The invention of a sprayer, used in the agriculture or horticulture sectorby the invention of sprayers, enable farmers to obtain maximum agricultural output.

But the existing sprayers has certain drawbacks like In conventional type pesticide sprayer, the heavy tank containing pesticide is carried by the person on his back and requires a lot of human efforts for spraying.

For spraying out the sanitizer one needs to hold the nozzle in the desired direction. Another type sprayer is fuel operated and requires expensive fuel i.e. Diesel or petrol.

Thus, the load on back of the person increases causes health issues. Such problems can be overcome by manually operated multi-nozzle sprayer as discussed in this project.

\section{Concept Idea of Product:}

The solution suggested by the proposed project is the use of multi-nozzle sprayer operated manually. Here rotary motion is converted into reciprocating motion manually. The handle is being pushed which causes the wheel to rotate. The chain sprocket arrangement is driven by the wheel, this in turn rotates the slider crank, creating pressure in piston pump. The amount of pressure created causes the pesticide from the tank to flow out of the tank. The pesticides propel out through the nozzle, connected to pump through a connecting rod.

\section{III - DETAILED CONCEPT}

Mechanisms used to achieve reciprocating motion:

- Motion transmission by chain and sprockets arrangement.

- $\quad$ Slider crank mechanism.

- All the components are designed in the software named Creo Parametric 2.0 And the analysis is done in Ansys software

A. Contents (Images of components used): -

1) Frame: -

It is main support system on which the model will be built. All the required components will be mounted on this frame as shown in fig. 1

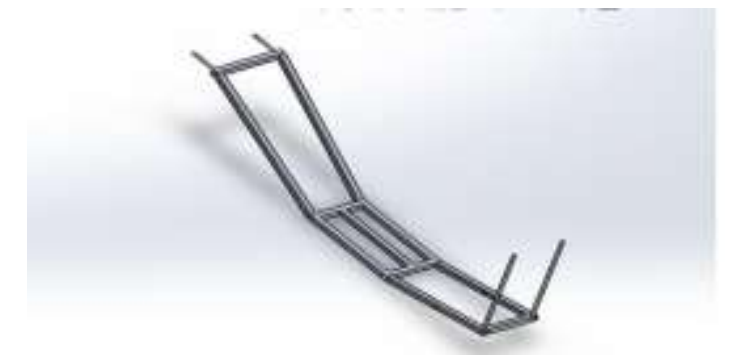

Fig. 1- Frame of the model 
Vol. 6, No. 7, 2021, PP. 28-32

\section{International Journal of Innovations in Engineering and Science, www.ijies.net}

Frame is made of $1.5 * 1.5$-inch aluminum bars of thickness $3 \mathrm{~mm}$ which can be easily welded.

Rest of the frame was designed considering its strength, stability and ergonomics. A bucket is attached to the frame for carrying extra stuff while spraying.

\section{2) Tank: -}

The tank is used to store the sanitizer which we will use to spray. The capacity of the tank would be approx. 16 litres. The weight of Tank $=4.3 \mathrm{~kg} * 9.8=42.14 \mathrm{~N}$

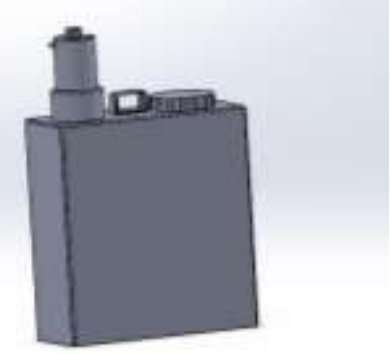

Fig. 2- Piston Tank Assembly

\section{3) Tank Holder: -}

It will support the tank as the weight of the tank is high due to the liquid sanitizer present in it. The tank holder will be mounted on the frame. The material used

is

Aluminium.

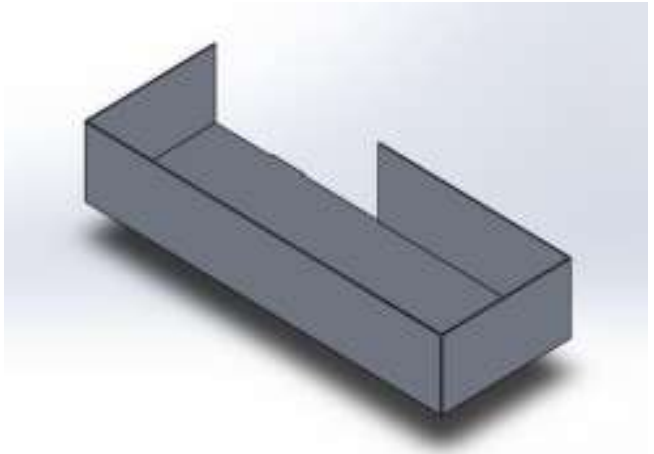

Fig. 3- Tank Holder

4) Wheel: -

Diameter of wheel $=50 \mathrm{~cm}$

The wheel will be of stainless steel

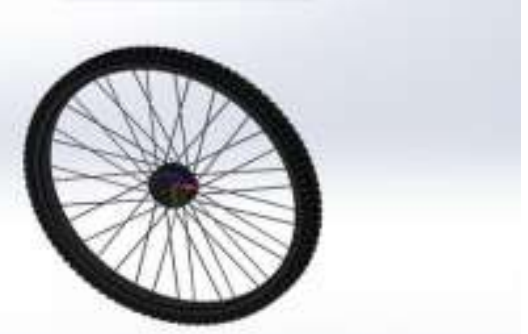

Fig. 5- Wheel
6) Chain Sprocket: -

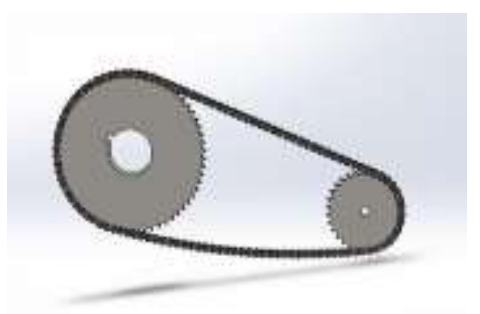

Fig. 6- Chain Sprocket

7) Driven Sprocket: -

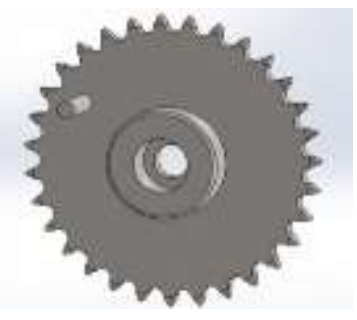

Fig. 7- Driven Sprocket

\section{B. Working of A Model}

The operator grabs the handle and pulls the trolley forward. As trolley moves forward, the wheel rotates in anti-clockwise direction. As sprocket is mounted on same shaft of wheel, it also rotates in anticlockwise direction. This motion is transferred to crank via chain drive arrangement and crank rotates anticlockwise as well. This will reciprocate the piston via connecting rod and builds up the pressure. During the upward motion of the connecting rod the sanitizer is drawn into the pump and during the downward motion of connecting rod the sanitizer is forced to the delivery valve, the delivery is connected to the pipe carrying the number of nozzles Thus, the sanitizer is sprayed. Height and angle of the nozzle bar can be adjusted by screw locking, which can be done manually.

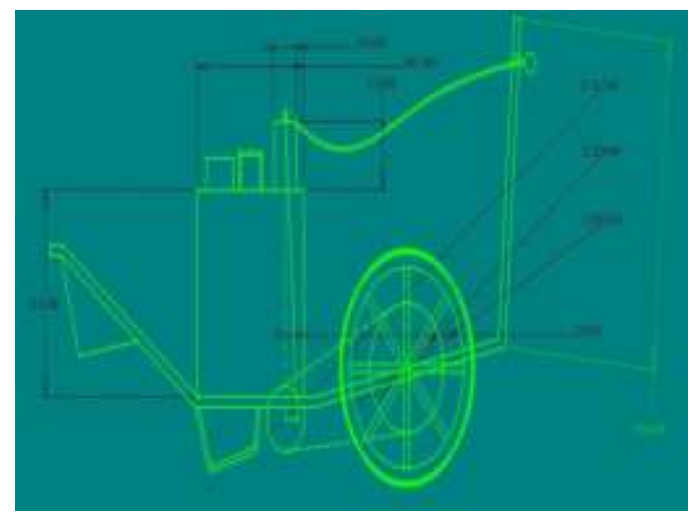

Fig. 8-2D image of the model 


\section{International Journal of Innovations in Engineering and Science, www.ijies.net}

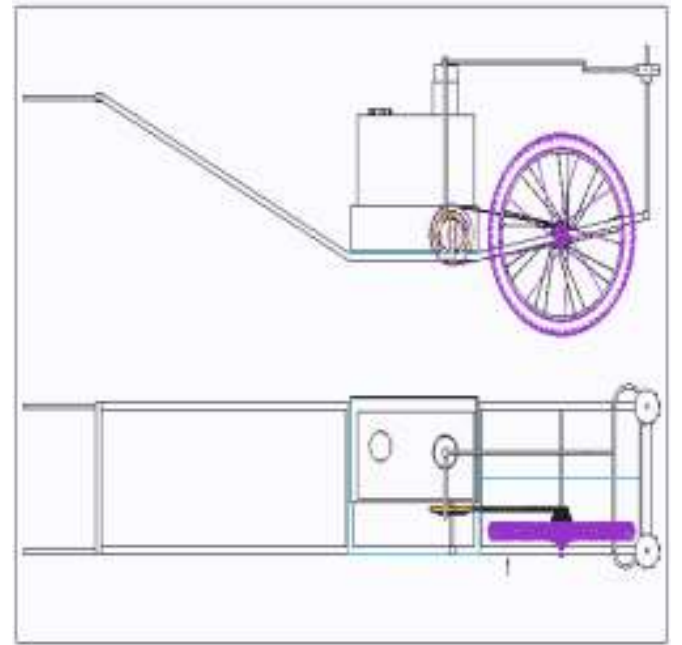

Fig. 9- Orthographic Projection

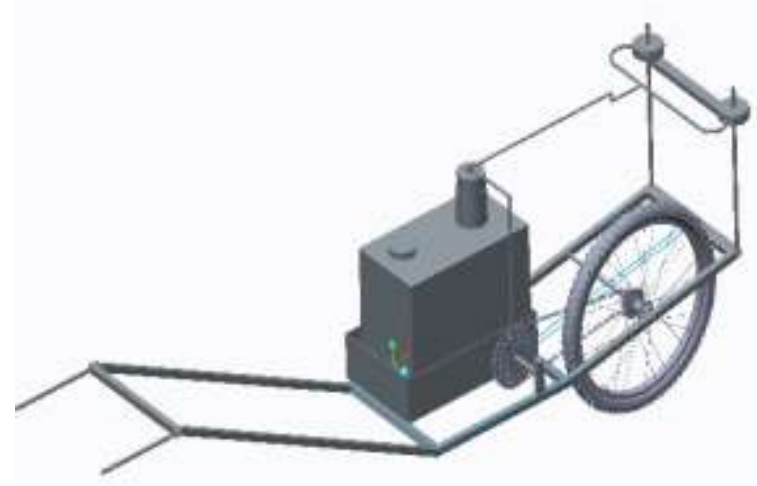

Fig. 10- Isometric view of model

\section{IV- RESULT \& ANALYSIS}

In the field of engineering design several advanced issues arrive, the Mathematical Formulation of that is tedious and typically impossible by analytical ways. At such instants we have a tendency to resort to the utilization of Numerical techniques. Here lies the importance of FEM that may be a very powerful tool for obtaining the Numerical solution of a good range of engineering issues.

Finite element method is that the micro mechanical analysis that is currently days used as a strong and an efficient tool for understanding the stress strain behavior of the structure. The fundamental idea within the Finite element method is to seek out the solution of difficult problem substitution it by the number of smaller regions. Thus, the solution of every region is taken into account as designed from several small interconnected sub-regions known as Finite elements.

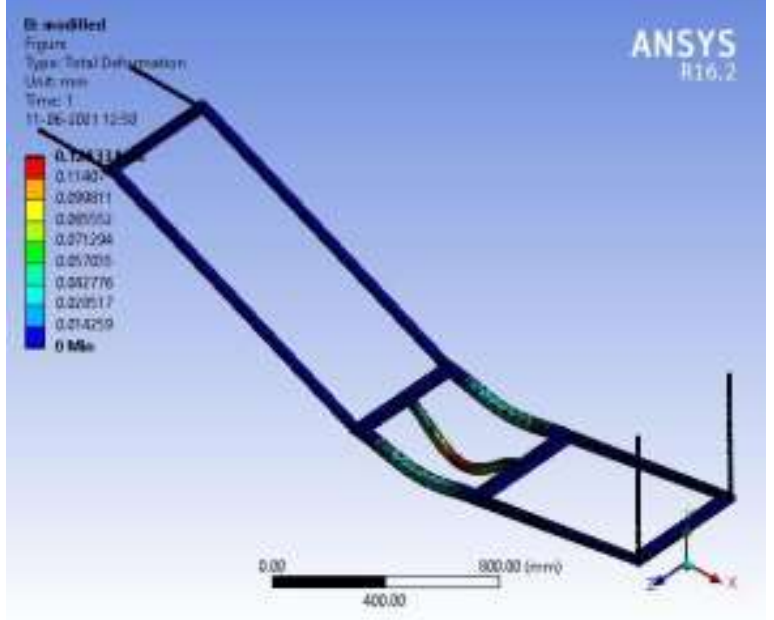

Fig.11- Total deformation of the model

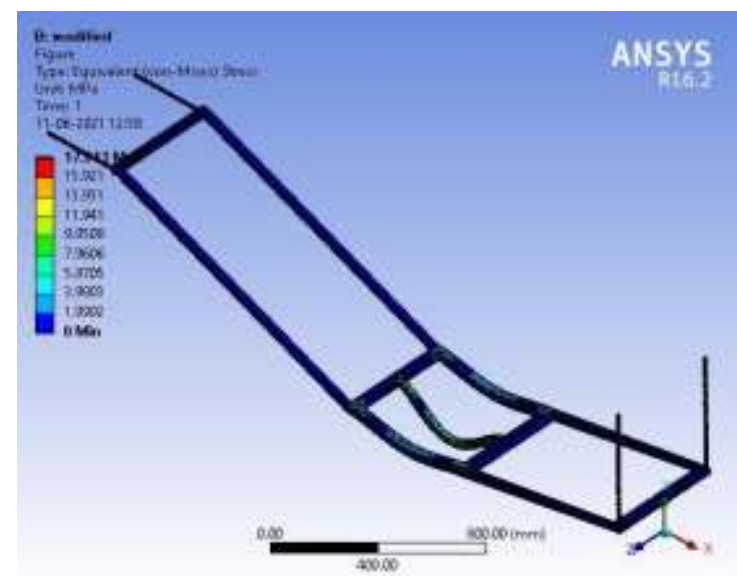

Fig.12 - Equivalent Stresses in model

It is easy to transport from one place to another. No use of fossil fuel or any other external source of energy. Reduces human fatigue and effort during spray and decrease the time of spraying the pesticides. Less manufacturing and maintenance cost. Multiple nozzles which cover maximum area of spraying in minimum time and at maximum rate as shown in fig. $11 \& 12$. Sanitizers can be sprayed on small as well as tall plants. Does not require to buy any Specially Designed Pump (conventional knapsack pump can be directly used here). Portable \& Ergonomic. No Running cost. It is Ecofriendly.

\section{V- CONCLUSION}

The motive behind developing this equipment is to create mechanizations which will help to minimize effort of farming. It is suitable for the spraying at minimum costs for the farmers so that he can afford it, of the many products available. As suggested model has a greater number of nozzles which will cover maximum area of spraying in minimum time $\&$ at maximum rate. Proper 


\section{International Journal of Innovations in Engineering and Science, www.ijies.net}

adjustment facility in the model with respect to crop helps to avoid excessive use of pesticides which result into less pollution. Imported hollow cone nozzles should be used in the field for better performance. This alone pump can used for multiple crops. We can spray up to height by using adjustable nozzle Design is optimized by increasing in size of cross section of the frame to handle the load acting because of various components and save materials and thus reducing costs.

More nozzles and circular fashion design is proposed to cover the maximum area. Mechanism can be added to increase the height of the nozzle rather than doing it manually. Two more wheels can be added to the frame so the user can directly push the vehicle without lifting it and lift while turning the vehicle.

Tank Size can be increased by proportionately changing the frame dimensions

\section{REFERENCES}

[1] Laukik P. Raut, Smit B. Jaiswal, Nitin Y. Mohite. (2013, Nov.) "Design, development and fabrication of agricultural pesticides sprayer with weeder", International Journal of Applied Research and studies(IJARS), pp. 1-8, ISSN: 2278-9480.

[2] Mohd. Hudzari Haji Razali. (2012, May). "Sprayer Technology for Farm Mechanization Course", Technical Journal of Engineering and Applied Science(TJEAS), pp. 107-112, ISSN: 20510853.

[3] Sandeep H. Poratkar and Dhanraj R. Raut. (2013, Mar.) "Development of Multinozzle Pesticides Sprayer Pump", International Journal of Modern Engineering Research (IJMER), Vol.3, Issue.2, pp864-868, ISSN: 2249-6645

[4] P.Madhu Raghava and Dr.Rajendra.( 7 July 2020) "Design and Fabrication of Dual Power Sprayer"International Research Journal on Advanced Science HUB, Volume O2, ISSN: 25824376

[5] J. P. MODAK, - Human Powered Flywheel Motor Concept, Design, Dynamics And Applications $\|$ Emeritus Professor of Mechanical Engineering and Dean $(R \& D)$, Priyadarshini College of Engineering, Near Central Reserve Police Force Campus, Hingna Road, MIDC, NAGPUR 440019 (INDIA).

[6] K. Bansal Laxmi Publication (P) Ltd.-Reference book.

[7] Machine Design (S. I. Units) By R.S. Khurmi\& J. K. Gupta-Reference book

[8] Pedro Wirz \& Lagos de Mores Panamericana, Compact Long Lasting Sprayer, Pump and Agitation Combination, International Journal of Engineering Research and Technology 11(2), 1996, 113-206
[9] Nitin Sawarkar, K.S. Zakiuddin, "Analysis Of Three Jaw Type Flexible Clutch", Zeichen Journa, Vol. 6, Issue 11, Pg. 180-188, Dec 2020.

[10] Nitin Sawarkar, Lokesh D. Mankar, Dr .Bharat Chede, Swapnil Choudhary "Investigation of Pipe Inspection Robot by using Commercial Package", Turkish Journal of Computer and Mathematics Education (TURCOMAT), Vol. no. 12, Issue 13, Pg.2264-2269, June 2021.

[11] V.N.Mujbaile, N.S.Sawarkar, Mangesh Gavhale, Swapnil Kawale, Ramesh Nagpure, "Design and Development of Solar Seed Dryer”, International Journal of Innovative Science, Engineering \& Technology, Vol.2, issue 4, pg.1005-1010, 2015

[12] Kalyani U Chafle, BM Faruk, RS Shrivas, NS Sawarkar, "Coin based mobile charger on solar energy" , International Journal Of Research Granthaalayah, Vol.3, Issue 1, pg.13-18, 2015.

[13] Sharayu D. Wasu, Ashish B. Khelkar, Atiq Z. Mirza, Dhananjay $V$. Bhile, "The experimental analysis applied to an evacuated tube solar collector equipped with solar parabolic trough and carbon filter for purification of water", Turkish Journal of Computer and Mathematics Education, Vol.12 No.13(2021), pg. 2274-2284, 2021.

[14] Dr Bharat Chede , Nitin Sawarkar , Swapnil Choudhary, Ajay Tinguria, "Scope of Digital Manufacturing in India after Covid-19", Turkish Journal of Computer and Mathematics Education, Vol.12 No.10 (2021), 4197-4201, 2021. 